\title{
Distribution of modern diatom assemblages among small playas
}

\author{
D. A. Boggs ${ }^{\mathrm{A}, \mathrm{D}}$, P. Gell ${ }^{\mathrm{B}}$, I. Eliot ${ }^{\mathrm{A}}$ and B. Knott ${ }^{\mathrm{C}}$ \\ ASchool of Earth and Geographical Sciences, The University of Western Australia, 35 Stirling Highway, \\ Crawley, WA 6009, Australia. \\ ${ }^{B}$ Department of Geographical and Environmental Studies, University of Adelaide, SA 5005, Australia. \\ ${ }^{\mathrm{C}}$ School of Animal Biology, The University of Western Australia, 35 Stirling Highway, Crawley, \\ WA 6009, Australia. \\ DCorresponding author. Email: dimity.boggs@cdu.edu.au
}

\begin{abstract}
Diatom diversity of six small playa lakes within the Yarra Yarra drainage system, Western Australia, and the environmental variables likely to influence their distribution was investigated. Thirty-one pennate diatom taxa were identified. Taxa consisted of facultative planktonic and periphytic, circumneutral to alkaliphilous or $\mathrm{pH}$-indifferent forms with known adaptations to saline conditions and fluctuations in salinity in $\mathrm{NaCl}$ dominated waters. Data were analysed by ordination (MDS and PCA), hierarchical clustering (CLUSTER), permutation-based hypothesis testing (ANOSIM) and comparative tests on similarity matrices (RELATE). Water depth accounted for the majority of variation in the environmental data. REALTE comparisons of environmental and taxa data did not produce a significant correlation value. We propose that the poor concurrence of the datasets was influenced by the wide ecological tolerances of the taxa recorded, some crucial unmeasured environmental variable/s, possible geographical regionalisation and/or unsampled taxa variability owing to the stochastic nature of the wetlands. Broad patterns of distribution were related to hydroperiod and some taxa groups were loosely associated with environmental groups consistent with established ecological tolerances for the taxa.
\end{abstract}

\section{Introduction}

Small playas ( $>10 \mathrm{ha}$ ) constitute numerically more than half of the salt lakes of the Yarra Yarra drainage system in the Yarra Yarra catchment area of Western Australia (Fig. 1) (Boggs et al. 2006). They are ephemeral and, while ionically similar, exhibit a range of hydrochemical environments through variable hydroperiods and filling frequencies brought about by rainfall and catchment variability (Boggs et al. 2007a). As well as being spatially variable, individual playas can be highly temporally irregular in terms of hydroperiod and can pass through several hydrochemical states (Boggs et al. 2007a) and resultant ecological regimes (Strehlow et al. 2005) in a single hydroperiod. Thus, there are several layers of hydrological and ecological variability operating in these wetlands.

Despite being a conspicuous element of the landscape and under serious threat from well documented land clearance and associated secondary-salinisation issues in the catchment (Henschke 1989; Clarke 2001; Regeneration Technology Pty Ltd 2001; Keighery 2004) only a handful of playas of the Yarra Yarra drainage system have been sampled for their aquatic biology in the past 25 years (see Brock and Lane 1983; Brock and Shiel 1983; Smith 2001; Blinn et al. 2004; Pinder et al. 2004, 2005; Boggs et al. 2007b). Systematic survey is likely to have been hindered by the unpredictability of hydroperiod, inaccessibility and socio-economic barriers such as the incompatibility of playas with agricultural land-use practices.

Recent broad-scale surveys of wetlands of the wider wheatbelt area (which lies roughly in the 600-300-mm rainfall zone of Western Australia and includes the Yarra Yarra drainage system) have identified that such wetlands are more important to the region's biodiversity than previously conceived (Halse et al. 2004). Surveys by Blinn et al. (2004) identified that wetlands of the wheatbelt not only have appreciable diatom diversity but that diatom assemblages are correlated with land-use practices. Consequently, in addition to their functional role as components of the benthic community, diatoms constitute bio-monitoring tools.

Diatoms as a bio-monitoring tool show a consistent tolerance to a wide range of environmental parameters such as light, moisture, $\mathrm{pH}$, salinity, oxygen and nutrients; they also respond rapidly to environmental change. Their application in monitoring change, and their relationships with major environmental variables in salt-lake environments, is well documented from locations world wide. Applications include using diatoms to predict drought periodicity, past climate conditions, salinity changes and water-body nutrient status (Gell and Gasse 1990; Servant-Vildary and Roux 1990; Gasse et al. 1997; Gell 1997; Gaiser et al. 1998; Reed 1998; Fritz et al. 1999; Saros and Fritz 2000, 2002; Gasse 2002).

Thus, given the importance of playas to biodiversity in the region and their status as threatened ecosystems and the potential of diatoms as bio-monitoring tools in such impacted ecosystems, the aim of the present research was to create an inventory of the diatom taxa present in six small playas of the Yarra Yarra drainage system and to determine the environmental variables that most influence their distribution. 


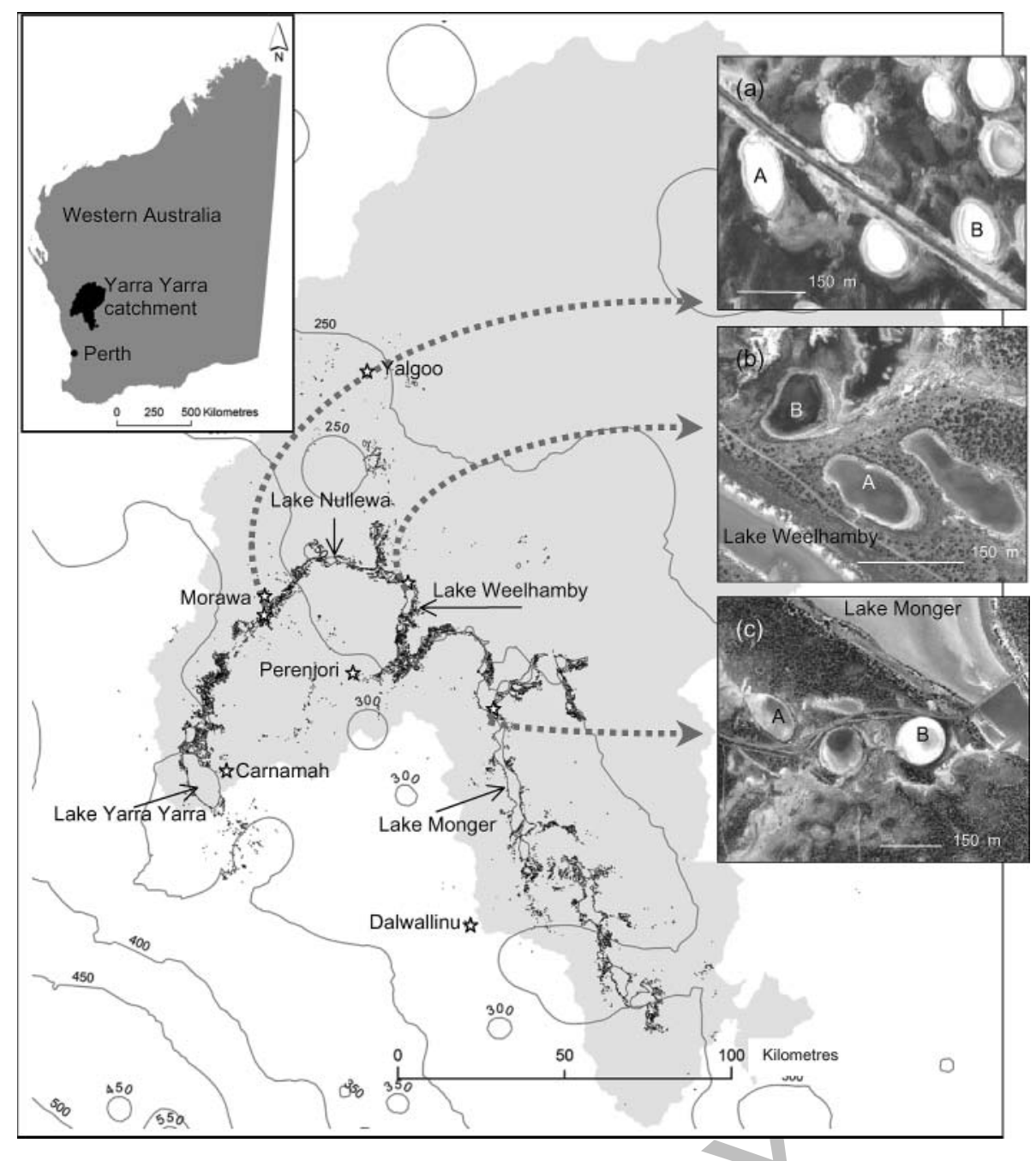

Fig. 1. The location of the Yarra Yarra catchment in Western Australia and the location of the six study playas in the Yarra Yarra drainage system: (a) Morawa A (MA) and Morawa B (MB), (b) Kadji A (KA) and Kadji B (KB) and (c) Mongers A (MONA) and Mongers B (MONB). Rainfall isohyets are indicated.

\section{Study area}

The Yarra Yarra drainage system comprises a chain of more than 4500 playas located in the northern wheatbelt of Western Australia, 300 km north-east of Perth (Fig. 1). Spanning several rainfall isohyets in the semi-arid zone of Western Australia, the average annual rainfall is $450 \mathrm{~mm}$ in the south-west of the catchment, decreasing to $200 \mathrm{~mm}$ in the north-east. This rainfall gradient generates variability in playa hydroperiod and filling frequency. The origin and geomorphology of the system has been discussed in detail elsewhere (Killigrew and Gilkes 1974; Beard 1999, 2000; Boggs et al. 2006).

Six small playas $\left(>3 \mathrm{~km}^{2}\right)$, comprising three pairs of adjacent lakes, were chosen for detailed investigation, and labelled Mongers A (MONA), Mongers B (MONB), Kadji A (KA), Kadji B (KB), Morawa A (MA) and Morawa B (MB). The playas are geomorphically similar and were chosen to represent a hydrological continuum from mostly wet (MONB) to mostly dry (KA), in order to investigate the effect of variable hydrological environments on diatom assemblages. The hydrochemistry of the playas is reported in Boggs et al. (2007a) and summarised in Table 1.

\section{Materials and methods}

\section{Sample acquisition and analysis}

Scrapes and surface waters were collected from the middle of each playa approximately weekly during wet phases. Scrapes of the top $3 \mathrm{~mm}$ of benthos were taken with a spoon. The sample jar was filled to a depth of $5 \mathrm{~mm}$ by this technique. In total, 48 scrapes with corresponding surface waters samples were taken between February 2002 and June 2004. The number of samples taken from each playa varied considerably, depending on the frequency and duration of inundation (Table 1).

Benthic material was stored in $100-\mathrm{mL}$ plastic vials and preserved in formalin diluted with lake water. In the laboratory, samples were homogenised and $\sim 1 \mathrm{~g}$ of sample used in 
Table 1. The location and hydrochemistry of the study lakes summarised from Boggs et al. in press

\begin{tabular}{|c|c|c|c|c|c|c|}
\hline Playa & Mongers A & Mongers B & Kadji A & Kadji B & Morawa A & Morawa B \\
\hline Location (UTM) & $\begin{array}{l}\text { 6731394E, } \\
470977 \mathrm{~N}\end{array}$ & $\begin{array}{l}\text { 6730831E, } \\
470970 \mathrm{~N}\end{array}$ & $\begin{array}{l}\text { 6769926E } \\
446696 \mathrm{~N}\end{array}$ & $\begin{array}{l}\text { 6769720E } \\
446638 \mathrm{~N}\end{array}$ & $\begin{array}{l}\text { 6763562E, } \\
403806 \mathrm{~N}\end{array}$ & $\begin{array}{l}\text { 6764320E, } \\
403795 \mathrm{~N}\end{array}$ \\
\hline $\begin{array}{l}\text { Brine type } \\
\quad \text { (Eugster and } \\
\text { Hardie 1978) }\end{array}$ & $\begin{array}{c}\mathrm{Na}-(\mathrm{Mg})-(\mathrm{Ca})- \\
\mathrm{Cl}^{-}\left(\mathrm{SO}_{4}\right) \\
\mathrm{Na}-(\mathrm{Mg})- \\
\mathrm{Cl}^{-}\left(\mathrm{SO}_{4}\right)\end{array}$ & $\begin{array}{c}\mathrm{Na}-(\mathrm{Mg})-(\mathrm{Ca})- \\
\mathrm{Cl}^{-}\left(\mathrm{SO}_{4}\right) \\
\mathrm{Na}-(\mathrm{Mg})- \\
\mathrm{Cl}^{-}\left(\mathrm{SO}_{4}\right)\end{array}$ & $\begin{array}{l}\mathrm{Na}-(\mathrm{Ca})-(\mathrm{Mg})- \\
\mathrm{Cl}^{-}\left(\mathrm{SO}_{4}\right) \\
\mathrm{Na}-(\mathrm{Ca})-(\mathrm{Mg})- \\
\mathrm{Cl}^{-}\left(\mathrm{SO}_{4}\right)\end{array}$ & $\begin{array}{c}\mathrm{Na}-(\mathrm{Mg})-(\mathrm{Ca})- \\
\mathrm{Cl}^{-}\left(\mathrm{SO}_{4}\right)\end{array}$ & $\begin{array}{l}\mathrm{Na}-(\mathrm{Ca})-(\mathrm{Mg})- \\
\mathrm{Cl}^{-}\left(\mathrm{SO}_{4}\right) \\
\mathrm{Na}-(\mathrm{Mg})-(\mathrm{Ca})- \\
\mathrm{Cl}^{-}\left(\mathrm{SO}_{4}\right)\end{array}$ & $\begin{array}{c}\mathrm{Na}-(\mathrm{Mg})-(\mathrm{Ca})- \\
\mathrm{Cl}^{-}\left(\mathrm{SO}_{4}\right) \\
\mathrm{Na}^{-}(\mathrm{Mg})- \\
\mathrm{Cl}^{-}\left(\mathrm{SO}_{4}\right)\end{array}$ \\
\hline $\mathrm{pH}$ range & $7.0-9.0$ & $6.8-9.7$ & $7.2-8.3$ & $7.0-7.8$ & $7.0-8.3$ & $6.6-7.8$ \\
\hline $\begin{array}{l}\text { Total dissolved } \\
\text { solids range } \\
\left(\mathrm{g} \mathrm{L}^{-1}\right)\end{array}$ & $20-162.8$ & $5.0-68.7$ & $7.6-20.7$ & $48.5-64.8$ & $64.8-197.5$ & $74.8-214.1$ \\
\hline Hydroperiod (days) & $44,84,33$ & $211,36+$ & 19 & & $<45$ & $<45$ \\
\hline Max depth (mm) & 450 & 1000 & 30 & 30 & 300 & 80 \\
\hline Total $n=$ & 18 & 21 & 2 & 2 & 7 & 6 \\
\hline$n$ used in analysis $=$ & 13 & 14 & 0 & 0 & 6 & 3 \\
\hline
\end{tabular}

slide preparation. Samples were prepared for diatom analysis following Ryves et al. (2001). Standard methods were modified by concentrating diatom frustules with sodium pyrophosphate, following Bates et al. (1978).

Water samples were stored in 500-mL plastic bottles and kept cool before analysis. Sample $\mathrm{pH}$ and total dissolved solids (TDS) were measured with a TPS conductivity-TDS-pH-temperature meter in the laboratory. Major cations and anions, $\mathrm{Ca}, \mathrm{K}, \mathrm{Mg}$, $\mathrm{Na}, \mathrm{SO}_{4}$ and $\mathrm{SiO}_{2}$ (ICPOES), $\mathrm{PO}_{4}$ (FIA), $\mathrm{Cl}\left(\mathrm{CL}_{2}\right)$ and $\mathrm{HCO}_{3}$ and $\mathrm{CO}_{3}$ (ALK1), were measured at the Northern Territory Environmental Laboratories according to standard methods (Eaton et al. 2005). Because of high TDS, some samples were diluted to reduce matrix effects.

Diatoms were identified by light microscopy at $\times 1000$ magnification with Nomarski optics and identified with the following keys; Krammer and Lange-Bertalot (1986, 1988, 1991), Gell et al. (1999) and Sonneman et al. (2000). Voucher collections are held by the University of Western Australia herbarium. In most cases, 200 diatom frustules were counted along transects, from two slides for each sample. Because of the rapid rate of dissolution in alkaline, saline environments (Flower 1993), all diatom cells were counted and considered 'alive' at the time of sampling.

\section{Statistical analysis}

Data were analysed in the PRIMER 6 (Plymouth Routines In Multivariate Ecological Research) computer software by the following methods: principal component analysis (PCA) to summarise patterns in environmental variables; multidimensional scaling (MDS) to further summarise patterns in both the environmental and taxa data; hierarchical clustering into sample or species groups (CLUSTER); analysis of similarity (ANOSIM) between CLUSTER groups in both the environmental and taxa data; and the RELEATE analysis which tests the relationship between multivariate pattern from two datasets, in this case the relationship between environmental and taxa data.

\section{Environmental data}

Correlated variables (correlations greater than 0.9) (Table 2) were removed from the data. Data were normalised and analysed using PCA for each lake separately and combined. Combined data were transformed with a Euclidean distance transformation and analysed with MDA and the group average CLUSTER method. Data were assigned FACTORS on the basis of the CLUSTER analysis. The FACTOR groups were tested for

Table 2. Environmental correlations for the combined dataset

\begin{tabular}{|c|c|c|c|c|c|c|c|c|c|c|c|c|}
\hline & Alkalinity & $\mathrm{Cl}$ & & K & $\mathrm{Mg}$ & $\mathrm{Na}$ & $\mathrm{SO}_{4}$ & $\mathrm{SiO}_{2}$ & $\mathrm{PO}_{4}$ & $\begin{array}{l}\text { Total dissolved } \\
\text { solids }\end{array}$ & $\begin{array}{l}\text { Water } \\
\text { depth }\end{array}$ & $\mathrm{pH}$ \\
\hline Alkalinity & 1.000 & & & & & & & & & & & \\
\hline $\mathrm{Cl}$ & 0.588 & 1.000 & & & & & & & & & & \\
\hline $\mathrm{Ca}$ & 0.353 & 0.394 & 1.000 & & & & & & & & & \\
\hline K & 0.641 & 0.968 & 0.350 & 1.000 & & & & & & & & \\
\hline $\mathrm{Mg}$ & 0.636 & 0.978 & 0.345 & 0.992 & 1.000 & & & & & & & \\
\hline $\mathrm{Na}$ & 0.550 & 0.993 & 0.413 & 0.969 & 0.978 & 1.000 & & & & & & \\
\hline $\mathrm{SO}_{4}$ & 0.591 & 0.979 & 0.437 & 0.978 & 0.987 & 0.983 & 1.000 & & & & & \\
\hline $\mathrm{SiO}_{2}$ & -0.189 & 0.092 & 0.414 & 0.081 & 0.091 & 0.044 & 0.009 & 1.000 & & & & \\
\hline $\mathrm{PO}_{4}$ & 0.580 & 0.263 & 0.246 & 0.329 & 0.329 & 0.264 & 0.272 & 0.053 & 1.000 & & & \\
\hline $\begin{array}{l}\text { Total dissolved } \\
\text { solids }\end{array}$ & 0.582 & 0.999 & 0.407 & 0.973 & 0.983 & 0.997 & 0.985 & 0.070 & 0.269 & 1.000 & & \\
\hline Water depth & -0.395 & 0.597 & 0.758 & 0.584 & 0.576 & 0.621 & 0.640 & 0.380 & -0.182 & 0.611 & 1.000 & \\
\hline $\mathrm{pH}$ & -0.351 & 0.532 & 0.490 & 0.535 & 0.531 & 0.561 & 0.564 & 0.151 & -0.357 & 0.546 & 0.612 & 1 \\
\hline
\end{tabular}


significant difference with ANOSIM. Samples codes used in the analysis are given in Appendix 1, available as an Accessory Publication on the web.

\section{Taxa data}

Taxa that represented less than $5 \%$ of the samples were removed from the data to reduce the effects of rare taxa. Raw taxa abundance data were transformed with a square-root transformation to down-weight the effects of dominant taxa, and analysed with MDS under a Bray-Curtis transformation and the group average CLUSTER method. Data were assigned FACTORS corresponding to the CLUSTER groups and analysed for significant differences with ANOSIM.

\section{RELATE}

Environmental data and taxa data were transformed with Euclidean distance and Bray-Curtis transformations, respectively, in PRIMER. The resulting matrices were tested for the strength of their correlation with the RELATE analysis with the Spearman rank correlation method.

\section{Short-term population change}

Data used in the statistical analysis were also graphed and in the $\mathrm{C} 2$ (v1.4) software through stratigraphic diagrams to investigate short-term population change of modern assemblages (Juggins 2003). Environmental variables derived from the PCA for each lake (Table 3) were plotted against taxa percentage abundances.

\section{Results}

\section{Sample analysis}

Diatomaceous material was found in all samples but in low abundance in seven samples that were consequently excluded from analyses (KA 10/05/03; KA 20/05/03; KB 10/05/03; KB 20/05/03; MA 19/10/03; MB 19/10/03; MONA 4/10/03). Thus, all samples taken from the Kadji playas were omitted thereby removing the material intended to represent the 'mostly dry' end of the hydrological continuum. Nonetheless, the remaining 41 samples were scored for diatoms. A total of 31 pennate diatom taxa was identified (Appendix 2, available as an Accessory Publication on the web). The taxa identified consisted of facultative planktonic and periphytic, circumneutral to alkaliphilous or $\mathrm{pH}$-indifferent forms, with known adaptations to saline conditions and fluctuations in salinity in $\mathrm{NaCl}-$ dominated waters. After data were reduced for statistical analysis, MA, MB, MONA and MONB had a total of 4, 3, 17 and 17 taxa, respectively (Fig. 2a).

\section{Analysis of environmental data}

The results of the PCA of environmental data are presented in Fig. $3 a . \mathrm{PC} 1$ and $\mathrm{PC} 2$ account for $69.8 \%$ of the variation in the data. For the combined data, the first PC was negatively correlated with water depth and $\mathrm{pH}$, and positively correlated with alkalinity calcium and TDS. PC2 had a strong positive correlation with $\mathrm{SiO}_{2}$ concentration and a negative correlation with alkalinity and water depth. Eigenvectors and Eigenvalues are given in Tables 3 and 4 .
Table 3. Eigenvectors for the PCA of each lake separately and the combined dataset

\begin{tabular}{|c|c|c|c|c|c|}
\hline Variable & PC1 & $\mathrm{PC} 2$ & PC3 & PC4 & PC5 \\
\hline \multicolumn{6}{|l|}{ Morawa A } \\
\hline Alkalinity & 0.544 & -0.365 & -0.176 & 0.058 & -0.037 \\
\hline $\mathrm{Ca}$ & -0.153 & -0.639 & -0.165 & 0.238 & -0.522 \\
\hline $\mathrm{SiO}_{2}$ & -0.521 & -0.15 & 0.24 & -0.452 & 0.161 \\
\hline $\mathrm{PO}_{4}$ & 0.282 & -0.511 & -0.037 & -0.475 & 0.504 \\
\hline $\begin{array}{l}\text { Total dissolved } \\
\text { solids }\left(\mathrm{g} \mathrm{L}^{-1}\right)\end{array}$ & 0.447 & 0.123 & 0.532 & 0.301 & 0.18 \\
\hline Water depth & 0.031 & 0.275 & -0.774 & 0.042 & 0.284 \\
\hline $\mathrm{pH}$ & & -0.288 & 0.021 & 0.646 & 0.576 \\
\hline \multicolumn{6}{|l|}{ Morawa B } \\
\hline Alkalinit & 0.472 & -0.314 & -0.155 & 0.45 & 0.672 \\
\hline $\mathrm{PO}_{4}$ & 0.425 & -0.534 & 0.569 & 0.057 & -0.455 \\
\hline TDS & 0.495 & 0.003 & -0.137 & -0.838 & 0.183 \\
\hline Water depth & -0.482 & -0.242 & 0.591 & -0.265 & 0.539 \\
\hline $\mathrm{pH}$ & 0.345 & 0.747 & 0.533 & 0.148 & 0.131 \\
\hline \multicolumn{6}{|l|}{ Mongers A } \\
\hline $\mathrm{Ca}$ & -0.514 & -0.17 & -0.35 & 0.112 & 0.405 \\
\hline $\mathrm{SiO}_{2}$ & 0.095 & -0.683 & 0.17 & -0.504 & -0.377 \\
\hline $\mathrm{PO}_{4}$ & -0.425 & 0.055 & 0.838 & -0.129 & 0.309 \\
\hline TDS & -0.538 & 0.04 & 0.058 & 0.412 & -0.732 \\
\hline Water depth & 0.398 & 0.472 & 0.289 & 0.109 & -0.182 \\
\hline $\mathrm{pH}$ & 0.313 & -0.527 & 0.243 & 0.732 & 0.172 \\
\hline \multicolumn{6}{|l|}{ Mongers B } \\
\hline Alkalinity & 0.36 & 0.495 & -0.559 & -0.439 & -0.299 \\
\hline $\mathrm{SiO}_{2}$ & 0.462 & 0.186 & 0.167 & 0.451 & -0.445 \\
\hline $\mathrm{PO}_{4}$ & 0.364 & -0.53 & -0.538 & -0.034 & 0.396 \\
\hline $\begin{array}{l}\text { Total dissolved } \\
\text { solids }\left(\mathrm{g} \mathrm{L}^{-1}\right)\end{array}$ & 0.367 & -0.544 & 0.393 & -0.469 & -0.403 \\
\hline Water depth & -0.411 & -0.374 & -0.463 & 0.297 & -0.612 \\
\hline $\mathrm{pH}$ & -0.471 & 0.052 & 0.031 & -0.543 & -0.138 \\
\hline \multicolumn{6}{|l|}{ Combined } \\
\hline$\overline{\text { Alkali }}$ & 0.419 & -0.406 & 0.16 & 0.336 & 0.126 \\
\hline $\mathrm{Ca}$ & 0.419 & 0.302 & -0.112 & 0.005 & -0.74 \\
\hline & 0.031 & 0.709 & 0.437 & 0.203 & 0.412 \\
\hline $\mathrm{PO}_{4}$ & 0.279 & -0.254 & 0.799 & -0.128 & -0.174 \\
\hline TDS & 0.441 & -0.211 & -0.297 & 0.314 & 0.372 \\
\hline Water depth & -0.444 & -0.358 & 0.179 & -0.216 & 0.007 \\
\hline $\mathrm{pH}$ & -0.421 & -0.063 & 0.111 & 0.827 & -0.314 \\
\hline
\end{tabular}

Cluster analysis of the data at a Euclidean distance of 2.4 produced nine groups of samples (Fig. 3). ANOSIM on the basis of these groups reveals that the groups are significantly different (significance level of sample statistic: $0.1 \%$ ) except in three cases between Groups 7 and 3, Groups 7 and 2, and Groups 4 and 2 (Table 5)

The environmental characteristics of each group of samples are summarised (Table 6). Some broad patterns are illustrated with bubble plots of environmental data, superimposed on top of the PCA with clusters in Fig. 4. Patterns observed show that Group 2 comprises deep-water, low-TDS, high-pH samples; Group 7 samples are high in $\mathrm{SiO}_{2}$ and $\mathrm{Ca}$; and Group 4 comprises shallow-water, high-TDS and -alkalinity samples. 

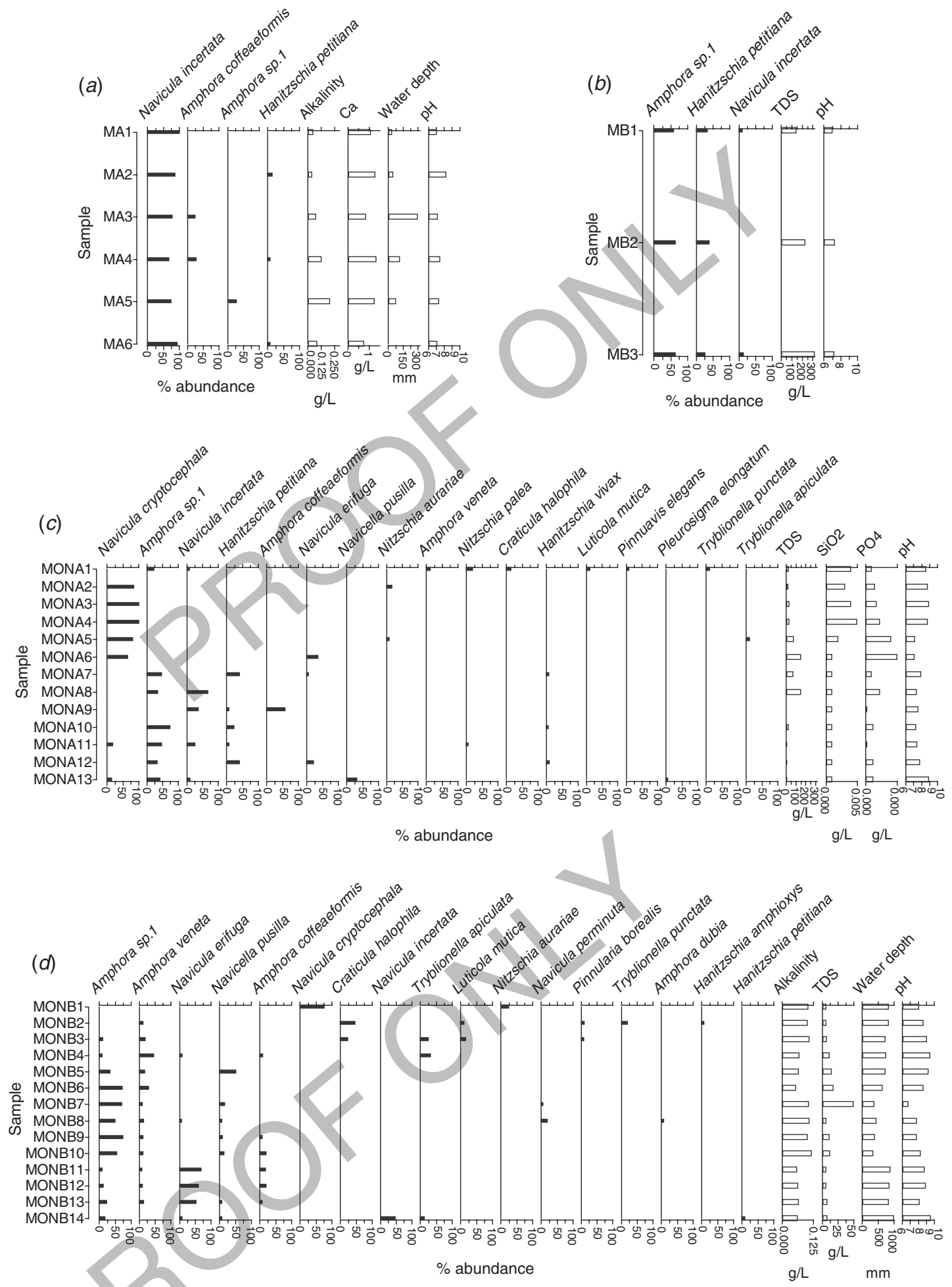

Fig. 2. Stratigraphic diagrams showing short-term change in diatom abundances during the monitoring period: (a) Morawa A (MA), (b) Morawa B (MB), (c) Mongers A (MONA) and (d) Mongers B (MONB). Environmental variables are from the PCA for each lake (Table 3). Authorities given in Appendix 2.

\section{Analysis of taxa data}

The results of the MDS are given in Fig. 5. The MDS had a relatively low stress level of 0.12 . Cluster analysis of the data at a Bray-Curtis similarity value of 40 produced five groups of samples (Fig. 5). ANOSIM on the basis of these groups revealed than less than half of the group combinations were significantly 


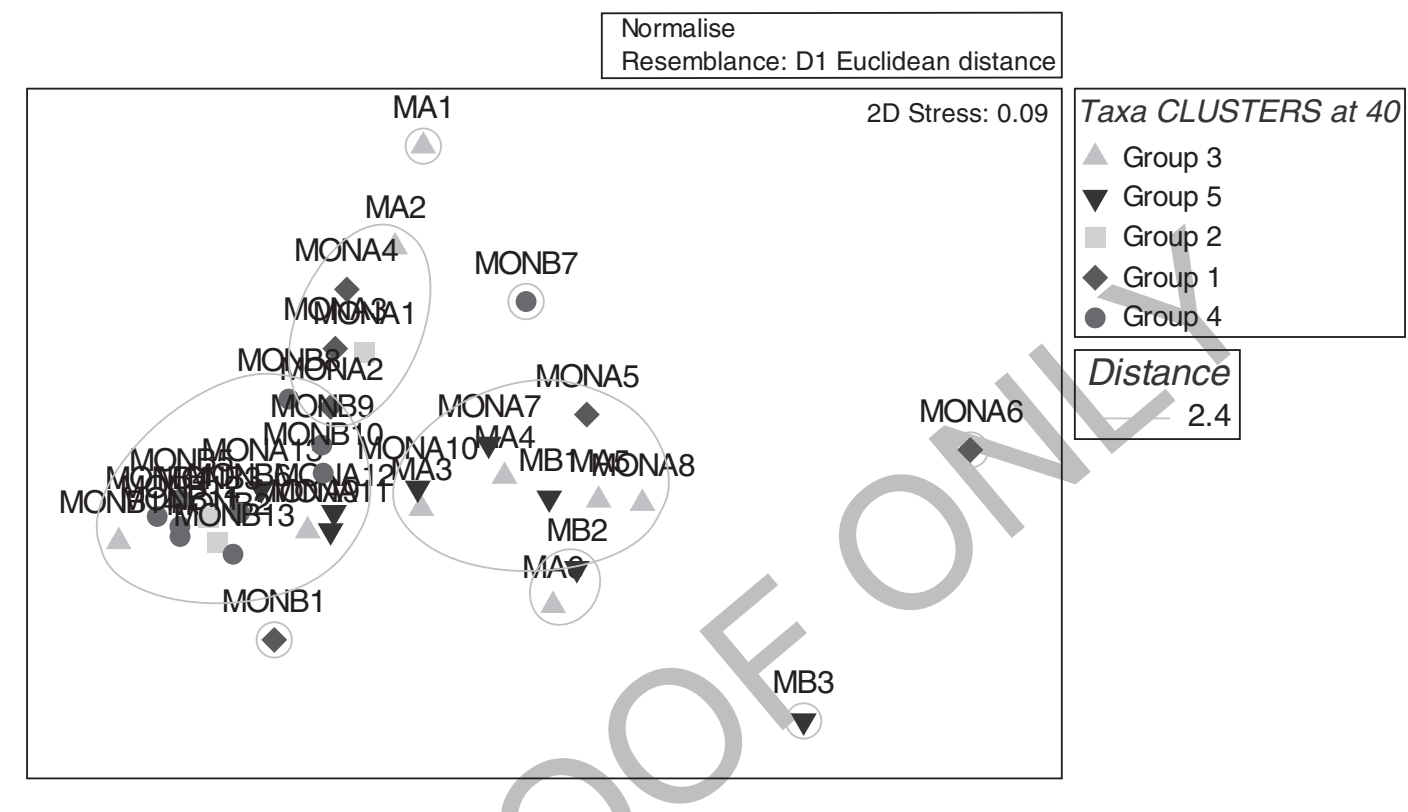

Fig. 3. MDS of environmental data with CLUSTERS at a Euclidean distance of 2.4 indicated by groups; and symbols representing the CLUSTERS of taxa data at a Bray-Curtis similarly of 40 .

Table 4. Eigenvalues for the PCA of each lake separately and the combined dataset

\begin{tabular}{|c|c|c|c|}
\hline $\mathrm{PC}$ & Eigenvalues & $\%$ Variation & Cum. \%Variation \\
\hline \multicolumn{4}{|c|}{ Morawa A } \\
\hline 1 & 2.34 & 33.4 & 33.4 \\
\hline 2 & 1.96 & 27.9 & 61.4 \\
\hline 3 & 1.39 & 19.9 & 81.3 \\
\hline 4 & 1.16 & 16.5 & 97.8 \\
\hline 5 & 0.155 & 2.2 & 100 \\
\hline \multicolumn{4}{|c|}{ Morawa B } \\
\hline 1 & 4.08 & 81.5 & 81.5 \\
\hline 2 & 0.924 & 18.5 & 100 \\
\hline 3 & 0 & 0 & 100 \\
\hline 4 & 0 & 0 & 100 \\
\hline 5 & 0 & 0 & 100 \\
\hline \multicolumn{4}{|c|}{ Mongers A } \\
\hline 1 & 3.13 & 52.1 & 52.1 \\
\hline 2 & 1.87 & 31.1 & 83.2 \\
\hline 3 & 0.594 & 9.9 & 93.1 \\
\hline 4 & 0.257 & 4.3 & 97.4 \\
\hline 5 & $8.54 \mathrm{E}-02$ & 1.4 & 98.8 \\
\hline \multicolumn{4}{|c|}{ Mongers B } \\
\hline 1 & 3.87 & 64.5 & 64.5 \\
\hline 2 & 1.01 & 16.8 & 81.3 \\
\hline 3 & 0.571 & 9.5 & 90.8 \\
\hline 4 & 0.297 & 5 & 95.7 \\
\hline 5 & 0.149 & 2.5 & 98.2 \\
\hline \multicolumn{4}{|c|}{ Combined } \\
\hline 1 & 3.46 & 49.4 & 49.4 \\
\hline 2 & 1.43 & 20.4 & 69.8 \\
\hline 3 & 0.934 & 13.3 & 83.1 \\
\hline 4 & 0.476 & 6.8 & 89.9 \\
\hline 5 & 0.416 & 5.9 & 95.8 \\
\hline
\end{tabular}

different (significance level of sample statistic: $0.1 \%$, Table 5).

Bubble plots of taxa abundance were superimposed on top of the MDS. Some examples are given in Fig. 6. A summary of the important taxa in each group are given in Table 6 . Several taxa were restricted entirely to one group, e.g. Navicula crypotocephala to Group 1; Craticula halophila to Group 2; and Hantzschia vivax to Group 5.

\section{Relationships between datasets}

The RELATE analysis produced a Spearman's $P$-value of 0.152 (significance level of sample statistic: $1.7 \%$ ) indicating that the environmental-data matrix and the taxa-data matrix are not significantly statistically correlated.

Environmental clusters superimposed on the MDS of taxa data (Fig. 5) give a visual indication of the relationships between the two datasets. There is notable overlap of Taxa Group 4 (Amphora veneta and Amphora sp.) and Environmental Group 2 (deep water, low TDS, high $\mathrm{pH}$ ). Taxa Group 1 (N. cryptocephala) overlaps with Environmental Group 7 (medium water depth and TDS and high $\mathrm{SiO}_{2}$ - not significantly different from Environmental Group 2). Taxa Group 2 (A. veneta) overlaps with Environmental Groups 2 and 7 (not found to be significantly different). Taxa Groups 3 and 5 overlap strongly with Environmental Groups 2 and 4 but also with Groups 3 and 6, indicating these taxa have wide ecological tolerances ( $C$. halophila and $A$. veneta). Navicula incertata was particularly euryhaline, being present in all sites at different times, under widely varying hydrochemical conditions.

\section{Short-term population change}

Stratigraphic diagrams showing short-term population changes in each lake are given in Fig. 2. All samples in MA were dominated by $N$. incertata, regardless of variation in the dominant environmental variables measured. Small incursions 
Table 5. Results of the ANOSIM between CLUSTER groups derived for the environmental and taxa data

\begin{tabular}{|c|c|c|c|}
\hline $\begin{array}{l}\text { Environmental } \\
\text { group }\end{array}$ & $\begin{array}{l}\text { Significance } \\
\text { statistic }\end{array}$ & $\begin{array}{l}\text { Possible } \\
\text { level \% }\end{array}$ & $\begin{array}{l}\text { Significant } \\
\text { difference }\end{array}$ \\
\hline Group 6, Group 7 & 0.96 & 16.7 & Yes \\
\hline Group 6, Group 4 & 1 & 11.1 & Yes \\
\hline Group 6, Group 3 & 1 & 33.3 & Yes \\
\hline Group 6, Group 2 & 0.999 & 5.9 & Yes \\
\hline Group 7, Group 4 & 0.907 & 0.1 & No \\
\hline Group 7, Group 3 & 1 & 4.8 & Yes \\
\hline Group 7, Group 8 & 1 & 16.7 & Yes \\
\hline Group 7, Group 9 & 1 & 16.7 & Yes \\
\hline Group 7, Group 2 & 0.815 & 0.1 & No \\
\hline Group 7, Group 1 & 1 & 16.7 & Yes \\
\hline Group 7, Group 5 & 1 & 16.7 & Yes \\
\hline Group 4, Group 3 & 0.47 & 2.2 & Yes \\
\hline Group 4, Group 8 & 1 & 11.1 & Yes \\
\hline Group 4, Group 9 & 1 & 11.1 & Yes \\
\hline Group 4, Group 2 & 0.891 & 0.1 & No \\
\hline Group 4, Group 1 & 1 & 11.1 & Yes \\
\hline Group 4, Group 5 & 0.929 & 11.1 & Yes \\
\hline Group 3, Group 8 & 1 & 33.3 & Yes \\
\hline Group 3, Group 9 & 1 & 33.3 & Yes \\
\hline Group 3, Group 2 & 0.998 & & Yes \\
\hline Group 3, Group 1 & 1 & 33.3 & Yes \\
\hline Group 3, Group 5 & 1 & 33.3 & Yes \\
\hline Group 8, Group 2 & & 5.9 & Yes \\
\hline Group 9, Group 2 & 1 & 5.9 & Yes \\
\hline Group 2, Group 1 & 0.752 & 5.9 & Yes \\
\hline Group 2, Group 5 & 0.991 & 5.9 & Yes \\
\hline $\begin{array}{l}\text { Taxa } \\
\text { group }\end{array}$ & $\begin{array}{l}\text { Significance } \\
\text { statistic }\end{array}$ & $\begin{array}{l}\text { Possible } \\
\text { level \% }\end{array}$ & $\begin{array}{l}\text { Significant } \\
\text { difference }\end{array}$ \\
\hline Group 3, Group 5 & 0.805 & 0.1 & No \\
\hline Group 3, Group 2 & 1 & 0.5 & Yes \\
\hline Group 3, Group 1 & 1 & 0.1 & No \\
\hline Group 3, Group 4 & 0.971 & 0.1 & No \\
\hline Group 5, Group 2 & 0.968 & 0.6 & Yes \\
\hline Group 5, Group 1 & 0.99 & 0.2 & Yes \\
\hline Group 5, Group 4 & 0.81 & 0.1 & No \\
\hline Group 2, Group 1 & 1 & 1.2 & Yes \\
\hline Group 2, Group 4 & 0.933 & 0.3 & Yes \\
\hline Group 1, Group 4 & 1 & 0.1 & No \\
\hline
\end{tabular}

of A. coffeaeformis occurred in samples MA4 and MA5. MB samples were consistently dominated by Amphora sp. with appreciable abundances of $H$. petitiana. MONA had two distinct phases of dominance, with $N$. cryptocephala, dominating in samples MONA2-MON6 corresponding to high levels of $\mathrm{SiO}_{2}$, and Amphora sp., $N$. incertata and $H$. petitiana co-dominating samples MONA7-13. MONA 1 did not have dominant taxa but had eight taxa co-occurring in abundances between 5 and $20 \%$. MONB1 and MONB2 were dominated by $N$. cryptocephala and $C$. halophila, respectively. MONB 3 was co-dominated by Amphora sp., A. veneta, C. halophila, T. apiculata and L. mutica. A. veneta occurred in all samples except MONB1 and MONB 14 but dominated only in sample MONB4. Amphora sp. dominated in samples MONB5-10, corresponding to low $\mathrm{pH}$ levels and low water depth. $N$. erifuga dominated samples MONB11-13 and $N$. incertata dominated sample MONB 14

\section{Discussion}

The taxa recorded are cosmopolitan and found in assemblages similar to other saline wetlands in Australia (Gell and Gasse 1990; Gell 1997; Blinn and Bailey 2001; Gell et al. 2002; Blinn et al. 2004) and the world (Ehrlich and Dor 1985; Servant-Vildary and Roux 1990). The number of taxa recorded is comparable to that found in recent studies in the region where similar wetlands with salinity $>30 \mathrm{~g} \mathrm{~L}^{-1}$ had fewer than 20 species (Blinn et al. 2004).

In contrast to previous studies, however, the results presented here reveal strong environmental patterns that generally do not correlate well statistically with their corresponding taxa data. There may be several possible explanations for this non-concurrence between datasets. First, many of the taxa recorded have broad ecological tolerance to a wide range in the environmental parameters measured. For example, $N$. incertata was euryhaline (4.22-325.1 $\mathrm{g} \mathrm{L}^{-1} \mathrm{TDS}$ ) and present at different times in all sites.

Second, diatom distribution may be driven by some variable/s other than, or in concert with, the 12 measured here. For example, Blinn et al. (2004) found in their study of wetlands of the wheatbelt of Western Australia that the composition of diatom assemblages was correlated with a combination of $\mathrm{pH}$, salinity, alkalinity and total phosphorus. Variation revealed in the present study may be related to multi-nutrient availability (N, P, Si, Fe), particularly given the location of the playas in an agricultural landscape where phosphate (superphosphate)- and nitrogen (urea)-based fertilisers are in heavy use (Van Gool and Runge 1996, 1997; Hamblin 2001). The availability of nutrients is complicated by ionic composition and concentration, namely the extracellular concentrations of $\mathrm{Na}^{2+}, \mathrm{K}^{+}$and $\mathrm{SO}_{4}{ }^{2-}$ which impact on $\mathrm{P}$ transport, $\mathrm{NO}_{3}{ }^{-}$uptake (through molybdate inhibition) and the uptake rate of silica (Saros and Fritz 2000, 2002). In the present study, known eutraphentic taxa such as L. mutica (Gell et al. 2002) did not occur reliably during periods of high $\mathrm{PO}_{4}$ in the surface waters. However, $\mathrm{PO}_{4}$ uptake may have been complicated by the coincidence of high TDS. Phosphate transport is promoted by $\mathrm{Na}^{2+}$ and inhibited by $\mathrm{K}^{+}$(Saros and Fritz 2002). TDS had very strong correlations with both $\mathrm{Na}^{2+}$ and $\mathrm{K}^{+}$, i.e. 0.99 and 0.97 , respectively. Strong relationships between agricultural land-use practices and diatom assemblages have been reported in at least two studies in Australia. Blinn and Bailey (2001) found diatom community structure in Australian streams to be strongly related to land use. Particularly relevant to our study is their finding that secondary salinisation and high phosphate levels related to agricultural practices reduced species richness and diversity, and that at high salinities, $\mathrm{PO}_{4}$ was driving community structure. Also, Blinn et al. (2004) found that diatom assemblages in wetlands of the wheatbelt of Western Australia were correlated with water-logging and salinisation resulting from land clearance.

Third, cluster analysis of the environmental variables did not necessarily group geographically proximate samples. However; clusters based on the taxa abundance tended to group samples that were physically adjacent. This also may be an artefact of neglecting crucial environmental variable/s and testament to the broad ecological tolerances of many of the species present. However, local recruitment may be important for driving species distribution. Indeed, the connectivity of the lakes through streams and waterfowl will be important for recruitment and 
Table 6. Summarised characteristics of the environmental and taxa groups identified through CLUSTER analysis

\begin{tabular}{|c|c|c|c|c|c|c|c|}
\hline $\begin{array}{l}\text { Environmental } \\
\text { cluster group }\end{array}$ & $\begin{array}{c}\text { Water } \\
\text { depth }(\mathrm{mm})\end{array}$ & $\begin{array}{c}\mathrm{SiO}_{2} \\
\left(\mathrm{mg} \mathrm{L}^{-1}\right)\end{array}$ & $\begin{array}{c}\mathrm{PO}_{4} \\
\left(\mathrm{mg} \mathrm{L}^{-1}\right)\end{array}$ & $\mathrm{pH}$ & $\mathrm{Ca}\left(\mathrm{mg} \mathrm{L}^{-1}\right)$ & $\begin{array}{l}\text { Total dissolved } \\
\text { solids }\left(\mathrm{g} \mathrm{L}^{-1}\right)\end{array}$ & Alkalinity \\
\hline 1 & 850 & 2 & 0.115 & 8.08 & 135 & 6.5 & 106 \\
\hline 2 & $350-1000$ & $1-4$ & $0.005-0.05$ & $7.46-9.57$ & $120-259$ & $4.2-17.9$ & $55-119$ \\
\hline 3 & $5-40$ & 1 & 0.005 & $7.13-7.35$ & $763-870$ & $229.8-241.3$ & $90-159$ \\
\hline 4 & $5-300$ & $1-2$ & $0.005-0.08$ & $7.06-7.93$ & $748-1550$ & $27.1-156.9$ & $76-219$ \\
\hline 5 & 390 & 4 & 0.125 & 6.79 & 818 & 71.74 & 107 \\
\hline 6 & 40 & 7 & 0.025 & 7.06 & 1070 & 35.81 & 51 \\
\hline 7 & $30-160$ & $3-5$ & $0.005-0.045$ & $8.3-8.92$ & $539-1290$ & $20-77.66$ & $40-101$ \\
\hline 8 & 20 & 1 & 0.08 & 7.28 & 304 & 325.1 & 302 \\
\hline 9 & 80 & 1 & 0.24 & & 1320 & 155.9 & 275 \\
\hline $\begin{array}{l}\text { Taxa cluster } \\
\text { group }\end{array}$ & Important taxa & & & & & & \\
\hline 1 & Navicula cryptocephala & & & & & & \\
\hline 2 & Craticula halophila Amphora veneta & & & & & & \\
\hline 3 & Navicula incertata & & & & & & \\
\hline 4 & Amphora sp. Amphora veneta & & & & & & \\
\hline 5 & Amphora sp. Hanitzschia vivax & & & & & & \\
\hline
\end{tabular}

(a)

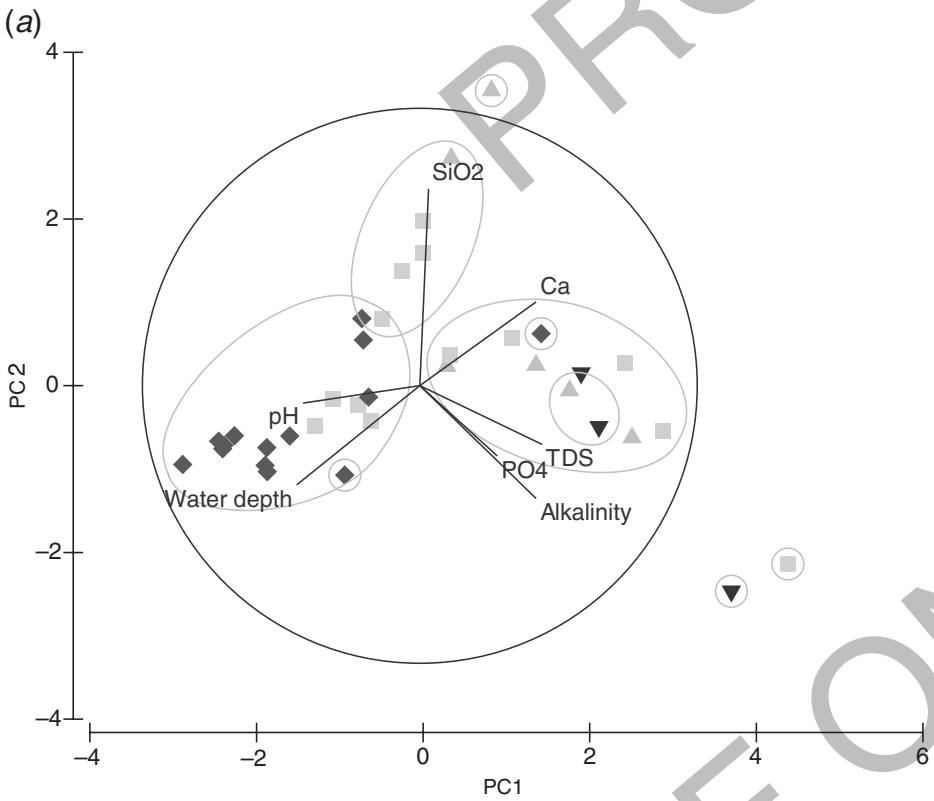

(e)

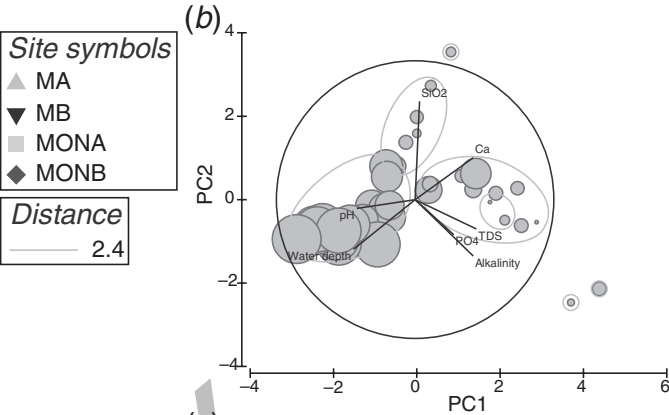

(c)

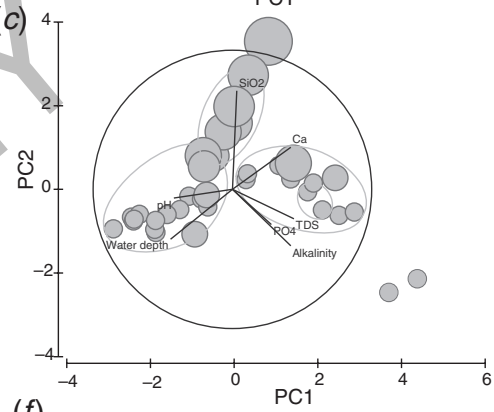

$(f)$
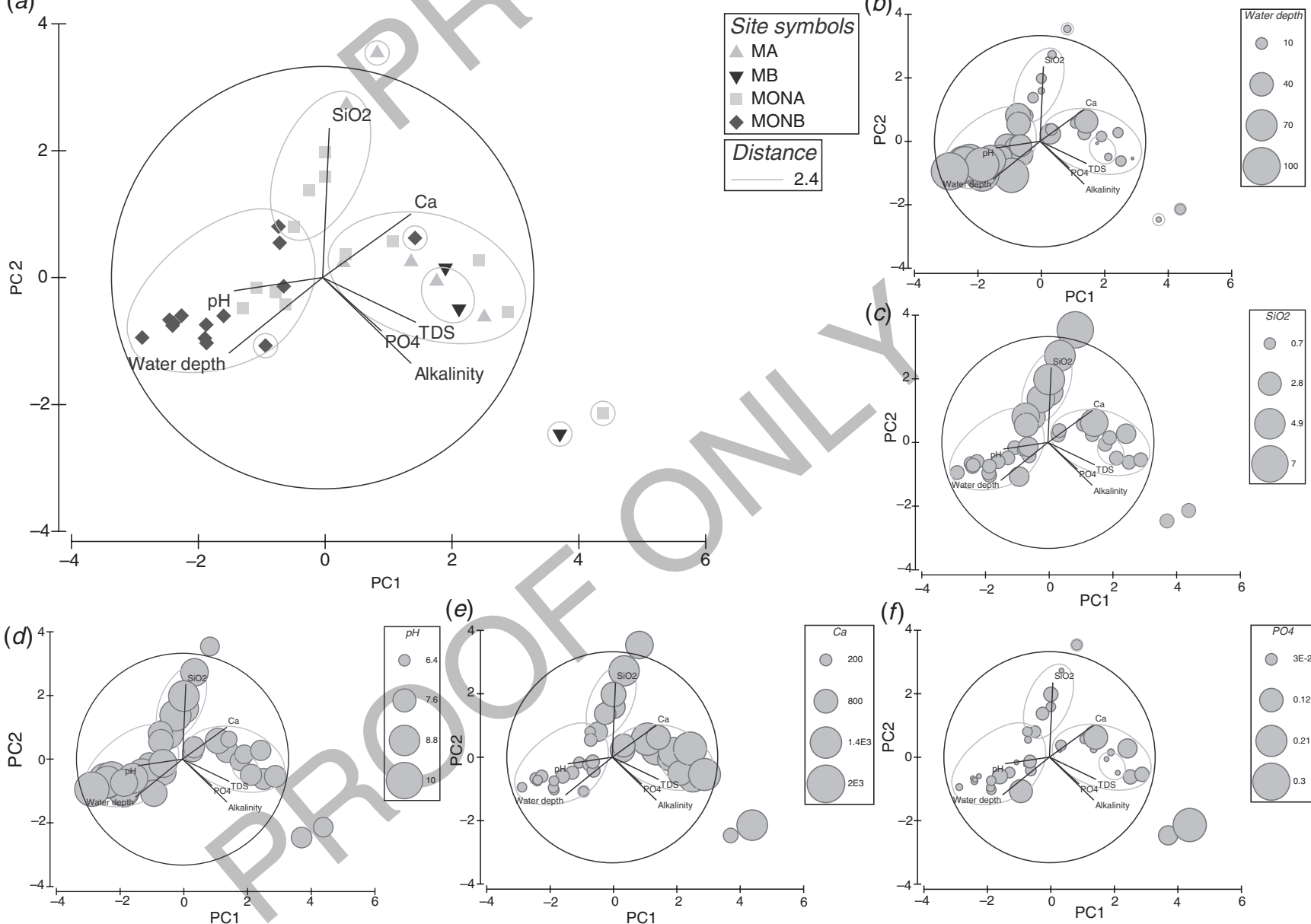

Fig. 4. (a) PCA plot of environmental variables with vectors and CLUSTERS at a Euclidean distance of 2.4 indicated; $(b)$ also with bubble plots of raw water depth data (c) $\mathrm{SiO}_{2},(d) \mathrm{pH},(e) \mathrm{Ca}$ and (f) $\mathrm{PO}_{4}$. 


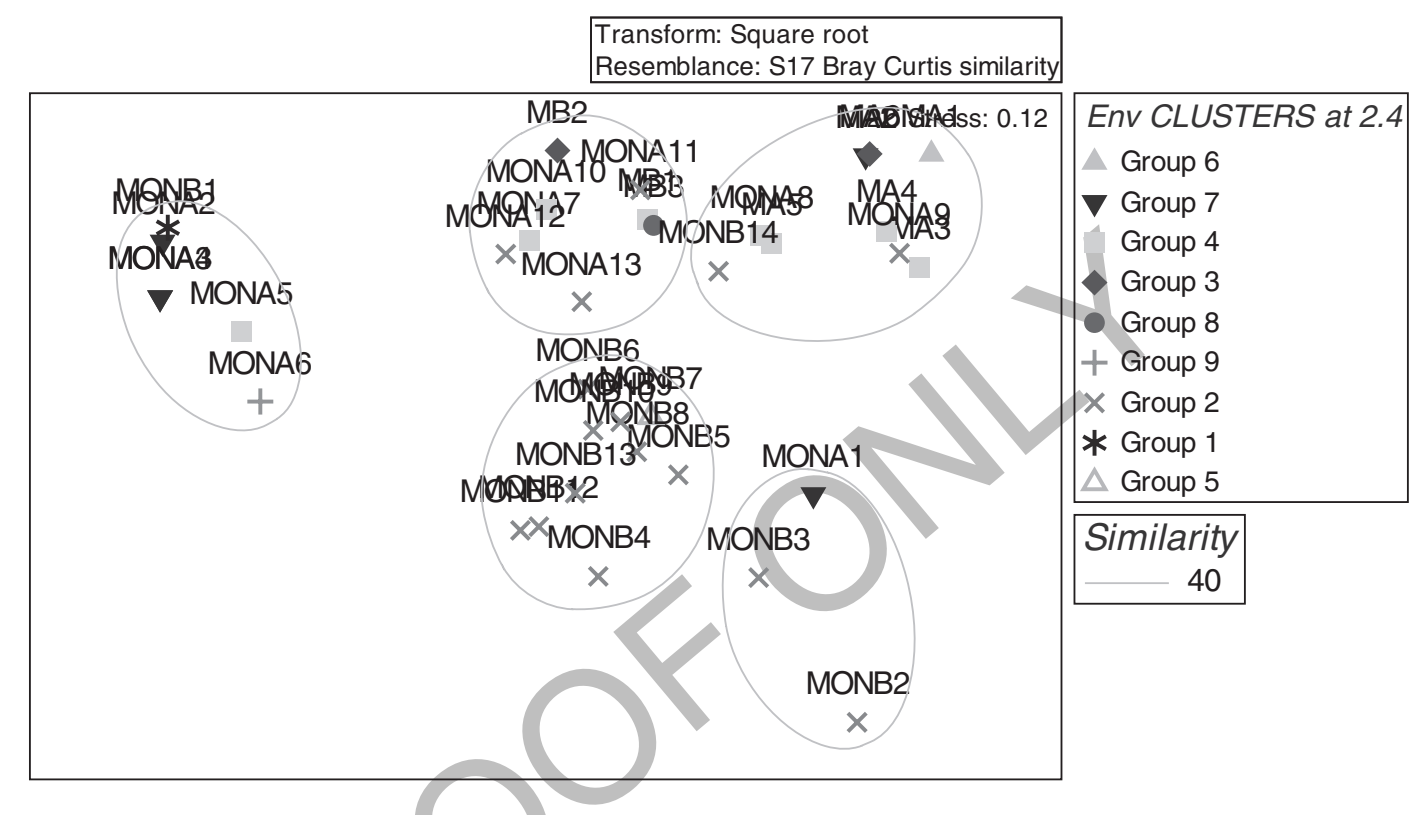

Fig. 5. MDS of taxa data with CLUSTERS at a Bray-Curtis similarity of 40 indicted by groups; and symbols representing the CLUSTERS of environmental data at a Euclidean distance of 2.4.

determining the proportion of Allochthonous diatoms. Small incursions of L. mutica, a known aerophilous taxon (Gasse 1986; Gell et al. 2002, 2005), following freshwater inputs in MONA and MONB suggest that the taxon may have been introduced with eroded sediments during filling. Regional zonation of assemblages could be investigated through a larger sample size coupled with remote sensing techniques to monitor playa connectivity through surface waters.

Fourth, the ephemeral playas of the Yarra Yarra drainage system are hydrologically stochastic environments. The microflora of these environments must needfully be opportunistic. In order to determine fully the range of taxa-environmental relationships that occur in these environments, a more detailed sampling regime than that presented here is required. The inter-annual variation in hydroperiod may mean that different taxa emerge year-to-year in response to patterns such as changes in the frequency of drying which is known to affect wetland productivity through the nutrient pulses that occur during flooding (Gawne and Scholz 2006). The differences in seasonal events may have implications for the future of research in playas of the region where predicted climate-change scenarios suggest that summer storms are likely to become more regular (Allan and Hunt 1999). The paucity of research on this scale in playas brings into question the applicability of diatom indicator species identified from other studies to these wetlands. For example, Blinn et al. (2004) identified that Hantzschia amphioxys, Nitzschia hybrida, Tryblionella hungarica and N. recta were numerically important taxa in wetlands with visible signs of salinisation. None of these taxa was found in high abundance in the research presented here, suggesting either that the six playas investigated are unaffected by secondary salt (unlikely), or that the taxa identified are not suitable indicators in naturally saline playa lakes.
Although the correlations between the environmental and taxa data are not statistically significant, visual comparison of the results reveal several trends. Almost half of the variation in the environmental data was related to water depth. If water depth is considered as a proxy for hydroperiod, and given that the six lakes sampled here represented a hydrological continuum (KA MONB), the number of taxa found in each lake can be described broadly as being positively related to hydroperiod. Long periods of drought (up to several years), and subsequent deflation of cysts from the lake floor, may have restricted the emergence of diatoms during wet phases in the Kadji playas (KA and $\mathrm{KB}$ ) which contained negligible, diatomaceous material. Conversely, the long hydroperiods of the Mongers playas (MONA and MONB) produced the highest total number of taxa. Hydroperiod has been investigated in its capacity to determine the distribution of diatoms elsewhere. Gaiser et al. (1998) recorded that diatom assemblages in the Carolina Bays, USA, had a strong linear relationship to hydroperiod, indicating that diatoms can be used to predict drought periodicity. In order to investigate further this relationship in the Yarra Yarra system would require a greater sample size than presented here; however, the application would be valuable for the system where a rainfall gradient extending SW-NE across the catchment is likely to generate a hydroperiod gradient.

Furthermore, it would be valuable to determine what role passive transport vectors such as wind, floodwaters, invertebrates and waterfowl play in recruiting diatoms to playas after long periods of desiccation. The south-west of Western Australia has been identified as an area of significant dust production (Prospero et al. 2002). Thus, the probability of resistant cysts being distributed by wind is high. Further, as the Yarra Yarra lakes are a loosely connected system, transport through surface waters during flood events is likely. Finally, the importance of invertebrates and waterfowl in the dispersal of diatoms has 


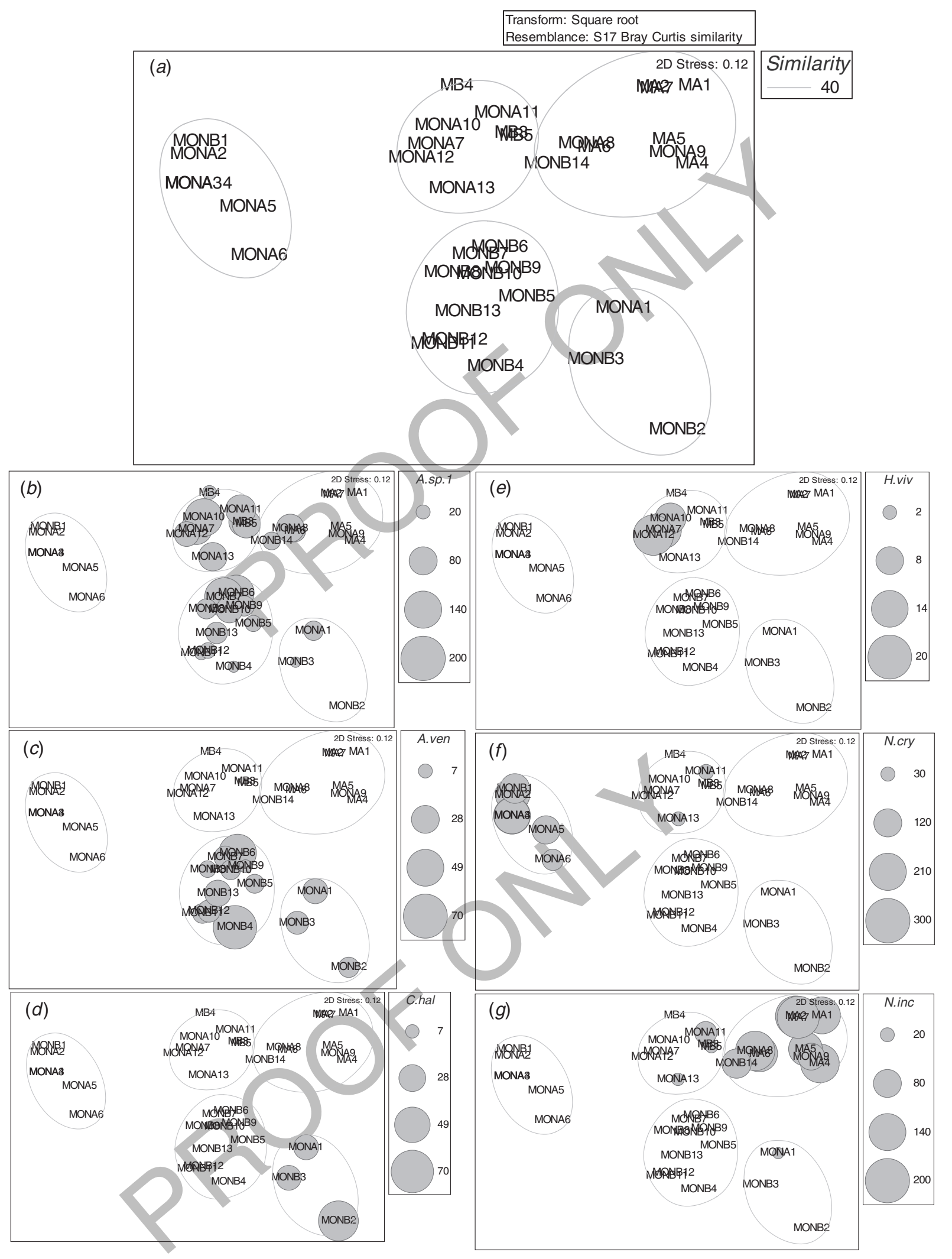

Fig. 6. (a) MDS plot of taxa data with CLUSTERS at a Bray-Curtis similarity of 40 indicted by groups; $(b)$ also with bubble plots of raw abundance data for Amphora sp.; (c) Amphora veneta, (d) Craticula halophila, (e) Hanitzschia vivax, $(f)$ Navicula cryptocephala and $(g)$ Navicula incertata. 
been established (Schlichting 1960; Schlichting and Sides 1969; Sides 1973; Wuthrich and Matthey 1980) but not thoroughly examined in Australia. Nonetheless, the abundance of waterbirds and invertebrates associated with playas in Australia (Geddes et al. 1981; Halse et al. 1994; Roshier et al. 2002; Cale et al. 2004; Pinder et al. 2005) provides a range of potential dispersal mechanisms.

An additional $20 \%$ of variance in the environmental data was related to the concentration of $\mathrm{SiO}_{2}$. Silica is a limiting variable for diatoms when nutrients are not limited (Smetacek 1998). Biogeochemical cycling of silica is important in structuring communities as it forms the diatom frustule. However, surface water silica may not be an entirely abiotic variable but partly a measure of biogenic silica (Clarke and Ainsworth 1993). Furthermore, as extracellular concentrations of $\mathrm{Na}^{2+}$ increase, so does the uptake rate of silicate (Saros and Fritz 2002). Therefore, further investigation of silica cycling in the lakes would be required to elucidate the relationship.

Visual comparison of the MDS graphs for both datasets and the stratigraphic diagrams show that there are some relationships that were not highlighted by the RELATE analysis. In particular, there is overlap between environmental cluster groups and taxa groups on the MDS. For example, overlap of Environmental Group 2 and Taxa Group 4 suggest that assemblages dominated by a combination of $A$. veneta and Amphora sp. are closely tied to a hydrological environment of 'deep' water (long hydroperiod), low TDS and neutral to high $\mathrm{pH}$. Similarly, the strong overlap of Taxa Group 3, dominated by $N$. incertata, and Environmental Group 2 show the affiliation of $N$. incertata for shallow, hypersaline conditions. However, $N$. incertata was also present in Environmental Groups 2, 3, 6 and 7, indicating it can tolerate a broad range of variables.

The stratigraphic diagrams show that the broad distributions of $N$. cryptocephala and $N$. incertata become dominant in low TDS and high TDS samples, respectively, in accordance with other records of the tolerances of the taxa (Gell 1997; Gell et al. 2002). The distribution of diatom species is often quoted as being highly correlated with salinity, or some correlated variable, and major anion composition (Gell and Gasse 1990; Saros and Fritz 2000). While the lakes had consistent major anion compositions dominated by $\mathrm{Na}$ and $\mathrm{Cl}$ (Table 1, and Boggs et al. 2007a), they had large ranges of salinity. For example, MONA fluctuated from 20.2 to $156.9 \mathrm{~g} \mathrm{~L}^{-1}$ during a 6-week hydroperiod. The failure of salinity to drive species distribution is likely to be related to several factors, including the wide ecological tolerances of many of the species recorded. Amphora sp. was euryhaline; presumably resulting from this, it is the only taxon that was dominant or co-dominant at some stage in all lakes. Other known euryhaline taxa such as $A$. coffeaeformis (Gell 1997) were patchily distributed and presumably limited by other factors.

\section{Conclusions}

Diatoms were collected from six small playa lakes to construct an inventory of the diatom taxa and determine the environmental variables that influence their distribution. The lakes were chosen to represent a hydrological continuum in order to investigate the effects of variable hydrological environments on species distribution. No unique taxa were recorded and the number of species present was typical of wetlands of this type. When compared through RELATE analysis, there was a poor correlation between the environmental and taxa datasets. This may be explained by a combination of the following four possible factors: (1) the broad ecological tolerances of many of the species present; (2) unmeasured environmental variable/s; (3) local recruitment and regional zonation; and/or (4) unrecorded variation in taxa due the stochasticity of the wetlands. However, visual comparison of the results suggests that diatom assemblages are positively related to hydroperiod, i.e. the mostly dry lakes (KA and $\mathrm{KB}$ ) contained negligible diatomaceous material while the mostly wet lakes (MONA and MONB) had the greatest number of taxa. These trends require validation through longer-term studies and a more detailed sampling regime. Nonetheless, the research identifies that the playas have significantly different hydrochemical environments that are habitat to an array of diatoms with potential as bio-monitoring tools for playas of the region.

\section{References}

Allan R, Hunt B (1999) 'Climate change modeling for the southern region of Western Australia.' (CSIRO Atmospheric Research: Melbourne)

Bates CD, Coxon P, Gibbard PL (1978) A new method for the preparation of clay-rich sediment samples for palynological investigation. New Phytologist 81, 459-463. doi: 10.1111/j.1469-8137.1978.tb02651.x

Beard JS (1999) Evolution of the river systems of the south-west drainage division, Western Australia. Journal of the Royal Society of Western Australia 82, 147-164.

Beard JS (2000) Drainage evolution in the Moore-Monger system, Western Australia. Journal of the Royal Society of Western Australia 83, 29-38.

Blinn DW, Bailey PCE (2001) Land-use influence on stream water quality and diatom communities in Victoria, Australia: a response to secondary salinisation, Hydrobiologia 466, 231-244. doi: 10.1023/A:1014541029984

Blinn DW, Halse SA, Pinder AM, Shiel RJ, McRae JM (2004) Diatom and micro-invertebrate communities and environmental determinants in the Western Australian wheatbelt: a response to salinisation. Hydrobiologia 528, 229-248. doi: 10.1007/s10750-004-2350-8

Boggs DA, Boggs GS, Eliot I, Knott B (2006) Regional patterns in salt lake morphology in the lower Yarra Yarra drainage system of Western Australia. Journal of Arid Environments 64, 97-115.

doi: 10.1016/j.jaridenv.2005.04.010

Boggs DA, Boggs GS, Eliot I, Knott B (2007a) The hydrology and hydrochemistry of six small playas in the Yarra Yarra system of Western Australia. Journal of the Royal Society of Western Australia 90(1), 15-32.

Boggs DA, Eliot I, Knott B (2007b) Salt lakes of the northern agricultural region, Western Australia. Hydrobiologia 576, 49-59.

doi: 10.1007/s10750-006-0292-z

Brock MA, Lane JAK (1983) The aquatic macrophyte flora of wetlands in Western Australia in relation to salinity and permanence. Hydrobiologia 105, 63-76. doi: 10.1007/BF00025177

Brock MA, Shiel RJ (1983) The composition of aquatic communities in saline wetlands in Western Australia. Hydrobiologia 105, 77-84. doi: 10.1007/BF00025178

Cale DJ, Halse SA, Walker CD (2004) Wetland monitoring in the wheatbelt of south-west Western Australia: site description, waterbird, aquatic invertebrate and groundwater data. Conservation Science of Western Australia 5, 20-135.

Clarke KR, Ainsworth M (1993) A method linking multivariate community structure to environmental variables. Marine Ecology Progress Series 92, 205-219. doi: 10.3354/meps092205 
Clarke M (2001) Yarra Yarra catchment executive summary RCA report. Department of Agriculture, Perth.

Eaton AD, Clesceri LS, Rice EW, Greenberg AE (Eds) (2005) 'Standard methods for the examination of water and wastewater.' 21st edn. (American Water Works Association: Washington, DC)

Ehrlich A, Dor I (1985) Photosynthetic microorganisms of the Gavish Sabkha. In 'Hypersaline ecosystems: the Gavish Sabkha'. (Eds GM Friedman, WE Krumbein) pp. 296-321. (Springer-Verlag: Berlin)

Flower RJ (1993) Diatom preservation: experiments and observations on dissolution and breakage in modern and fossil material. Hydrobiologia 269-270, 473-484. doi: 10.1007/BF00028045

Fritz SC, Cumming BF, Gasse F, Laird KR (1999) Diatoms as indicators of hydrologic and climatic change in saline lakes. In 'The diatoms: applications for the environmental and earth sciences'. (Eds EF Stoermer, JP Smol) pp. 41-71. (Cambridge University Press: Cambridge)

Gaiser EE, Philippi TE, Taylor BE (1998) Distribution of diatoms among intermittent ponds on the Atlantic Coastal Plain: development of a model to predict drought periodicity from surface-sediment assemblages. Journal of Paleolimnology 20, 71-90. doi: 10.1023/A:1007969500673

Gasse F (1986) East African diatoms and water pH. In 'Diatoms and lake acidity'. (Eds JP Smol, RW Battarbee, RB Davis, J Merilainen) pp. 149-169. (Dr. W. Junk Publishers: Dordrecht, The Netherlands)

Gasse F, Barker P, Gell P, Fritz SC, Chalie F (1997) Diatom-inferred salinity in palaeolakes: an indirect tracer of climate change. Quaternary Science Reviews 16, 547-563. doi: 10.1016/S0277-3791(96)00081-9

Gasse F (2002) Diatom-inferred salinity and carbonate oxygen isotopes in Holocene waterbodies of the western Sahara and Sahel (Africa). Quaternary Science Reviews 21, 737-767. doi: 10.1016/S0277-3791(01)00125-1

Gawne B, Scholz O (2006) Synthesis of a new conceptual model to facilitate management of ephemeral deflation basins. Lakes and Reservoirs: Research and Management 11, 177-188. doi: 10.1111/j.1440-1770.2006.00304.x

Geddes MC, DeDeckker P, Williams WD, Morton DW, Topping M (1981) On the chemistry and biota of some saline lakes in Western Australia. Hydrobiologia 81-82, 201-222. doi: 10.1007/BF00048717

Gell P (1997) The development of a diatom database for inferring lake salinity, western Victoria, Australia: towards a quantitative approach for reconstructing past climates. Australian Journal of Botany 45, 389-423. doi: 10.1071/BT96036

Gell P, Gasse F (1990) Relationships between salinity and diatom flora from some Australian saline lakes. In 'Proceedings of the 11th international diatom symposium'. (Ed. JP Kociolek) pp. 631-647. (California Academy of Sciences: San Francisco)

Gell P, Sonneman JA, Reid MA, Illman MA, Sincock AJ (1999) 'An illustrated key to common diatom genera from southern Australia.' (Cooperative Research Centre for Freshwater Ecology: Thurgoona, NSW)

Gell P, Sluiter IR, Fluin J (2002) Seasonal and interannual variations in diatom assemblages in Murray River connected wetlands in north-west Victoria, Australia. Marine and Freshwater Research 53, 981-992. doi: 10.1071/MF01021

Gell P, Tibby J, Fluin J, Leahy P, Reid MA, Adamson K, Bulpin S, MacGregor A, Wallbrink P, Hancock G, Walsh B (2005) Accessing limnological change and variability using fossil diatom assemblages, south-east Australia. River Research and Applications 21, 257-269. doi: $10.1002 /$ rra. 845

Halse S, Vervest RM, Pearson GB, Yung FH, Fuller PJ (1994) Annual waterfowl counts in south-west Western Australia-1990/91. CALMScience 1, 107-129.

Halse SA, Lyons MN, Pinder AM, Shiel RJ (2004) Biodiversity patterns and their conservation in wetlands of the Western Australian wheatbelt. Records of the Western Australian Museum. 67, 337-364.
Hamblin A (2001) Land theme report. CSIRO, Australia.

Henschke CJ (1989) Catchment salinity: report on a study of the East Perenjori catchment. No. 85. Western Australian Department of Agriculture, Perth

Juggins S (2003) ' $\mathrm{C}^{2}$ user guide. Software for ecological and palaeoecological data analysis and visualisation.' (University of Newcastle: Newcastle Upon Tyne, UK)

Keighery GJ (2004) State salinity strategy biological survey of the Western Australian wheatbelt: background. Records of the Western Australian Museum 67, 1-6.

Killigrew LP, Gilkes RJ (1974) Development of playa lakes in south Western Australia. Nature 247, 454 455. doi: 10.1038/247454a0

Krammer K, Lange-Bertalot H (1986) 'Susswasserflora von Mitteleuropa. Bacillariophyceae. Teil 1: Naviculaceae.' (Gustav Fischer Verlag: Jena)

Krammer K, Lange-Bertalot H (1988) 'Susswasserflora von Mitteleuropa. Bacillariophyceae. Teil 2: Bacillariaceae, Epithemiaceae, Surirellaceae.' (VEB Gustav Fischer Verlag: Jena)

Krammer K, Lange-Bertalot H (1991) 'Susswasserflora von Mitteleuropa. Bacillariophyaceae. Teil 3: Centrales, Fragilariaceae, Eunotiaceae.' (VEB Gustav Fischer Verlag: Jena)

Pinder AM, Halse S, Shiel RJ (2004) Aquatic invertebrate assemblages of wetlands and rivers in the wheatbelt region of Western Australia. Records of the Western Australian Museum 67(Suppl.), 7-37.

Pinder AM, Halse SA, McRae JM, Shiel RJ (2005) Occurrence of aquatic invertebrates of the wheatbelt region of Western Australia in relation to salinity. Hydrobiologia 543, 1-24. doi: 10.1007/s10750-004-5712-3

Prospero JM, Ginoux P, Torres O, Nicholson S (2002) Environmental characterization of global sources of atmospheric soil dust derived from the NIMBUS-7 TOMS absorbing aerosol product. Reviews of Geophysics 40, 1002-1032. doi: 10.1029/2000RG000095

Reed JM (1998) Diatom preservation in the recent sediment record of Spanish saline lakes: implications for palaeoclimate study. Journal of Paleolimnology 19, 129-137. doi: 10.1023/A:1007948600780

Regeneration Technology (2001) 'Ecological assessment of the Yarra Yarra catchment.' Prepared for the Yarra Yarra Catchment Group. Available at http://www.regentec.com.au

Roshier DA, Robertson AI, Kingsford RT (2002) Responses of waterbirds to flooding in an arid region of Australia and implications for conservation. Biological Conservation 106, 399-411. doi: 10.1016/S0006-3207(01)00268-3

Ryves DB, Juggins S, Fritz SC, Battarbee RW (2001) Experimental diatom dissolution and the quantification of microfossil preservation in sediments. Palaeography, Palaeoclimatology, Palaeoecology 172, 99-113. doi: 10.1016/S0031-0182(01)00273-5

Saros JE, Fritz SC (2000) Nutrients as a link between ionic concentration/composition and diatom distributions in saline lakes. Journal of Paleolimnology 23, 449-453. doi: 10.1023/A:1008186431492

Saros JE, Fritz SC (2002) Resource competition among saline-lake diatoms under varying N/P ratio, salinity and anion composition. Freshwater Biology 47, 87-95. doi: 10.1046/j.1365-2427.2002.00781.x

Schlichting HE (1960) The role of water fowl in dispersal of algae. Transactions of the American Microscopical Society 79, 160-166. doi: $10.2307 / 3224082$

Schlichting HE, Sides SL (1969) The passive transport of aquatic microorganisms by selected Hemiptera. Journal of Ecology 57, 759-764. doi: 10.2307/2258497

Servant-Vildary S, Roux JM (1990) Multivariate analysis of diatoms and water chemistry on Bolivian saline lakes. Hydrobiologia 197, 267-290. doi: 10.1007/BF00026956

Sides SL (1973) Internal and external transport of algae and protozoa by sea gulls. Transactions of the American Microscopical Society 92, 307-311. doi: $10.2307 / 3224934$ 
Smetacek V (1998) Diatoms and the silicate factor. Nature 391, 224-225. doi: $10.1038 / 34528$

Smith DA (2001) A comparison of benthic microbial mats in adjacent, ephemeral salt lakes. Honours Thesis, The University of Western Australia.

Sonneman JA, Sincock AJ, Fluin J, Reid MA, Newall P, Tibby J, Gell P (2000) 'An illustrated guide to common stream diatom species from temperate Australia.' (Cooperative Research Centre for Freshwater Ecology: Sydney)

Strehlow K, Davis J, Sim L, Chambers J, Halse S, Hamilton D, Horwitz P, McComb A, Froend R (2005) Temporal changes between ecological regimes in a range of primary and secondary salinised wetlands. Hydrobiologia 552, 17-31. doi: 10.1007/s10750-005-1502-9
Van Gool D, Runge W (1996) Atlas of Western Australian agricultural statistics, 15/96. Agriculture Western Australia, Perth.

Van Gool D, Runge W (1997) Atlas of Western Australian agricultural statistics 1994/95, 14/97. Agriculture Western Australia, Perth.

Wuthrich M, Matthey W (1980) The diatoms of the 'Tourbiere du Cachot" peat bogs (Swiss Jura Mountains). III. Transport of diatoms by wind, waterbirds and aquatic insects. Schweizerische Zeitschrift für Hydrologie 42, 269-284. doi: 10.1007/BF02502438

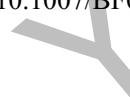

Manuscript received 16 May 2006, accepted 1 October 2007 


\section{AUTHOR QUERIES}

Q1 AU: Figs 3, 5, 7 text parts merged with one another pls. check. 